\title{
The Study of Critical Eco-Linguistic in Green Discourse: Prospective Eco-Linguistic Analysis
}

\author{
Tommi Yuniawan, Fathur Rokhman, Rustono, Hari Bakti Mardikantoro \\ Universitas Negeri Semarang \\ E-mail: tommiyuniawan@mail.unnes.ac.id
}

\begin{abstract}
This study aims to describe green discourse seen from critical eco-linguistic perspective. Critical eco-linguistic is a combination of eco-linguistic and critical discourse analysis. Critical eco-linguistic examines the environmental discourse and various forms of discourses and their ideology which concerns people and the environment. This research uses descriptive approach. The data of this study are texts on green discourse taken from www.unnes.ac.id, Suara Merdeka newspaper, and Kompas news paper. Methods of data the collections are listening, literature study, and documentation. The data were analyzed by the critical eco-linguistic study. Based on the data analysis, in the green discourse texts, the lingual units found represent ideological, sociological, and biological meaning. Utilization of lingual units in green discourse will affect the sense and logic of people involved in the discourse, ie the writers and readers or the speakers and the speakers. If green discourse is constructive, then their attitude and actions to the environment are constructive. Conversely, if green discourse is more destructive and exploitative, then their attitudes and actions towards the environment will also be affected towards destruction and exploitation. For this reason, critical eco-linguistic studies in green discourse deserve to be given space as a form of prospective eco-linguistic analysis.
\end{abstract}

Keywords: critical eco-linguistic; green discourse

\section{INTRODUCTION}

The discourse about the environment or can be called green discourse is often found in everyday life, namely in print media such as newspapers and magazines, as well as electronic media such as radio, television and internet. Audience knows some environment-related terms that have been created by language or environmental experts with the help of journalists through the mass media. This is because the media play a role, and has the power and dominance, which will be directly or will not affect the life of society.

The balance between formal linguistic studies and critical linguistics, including critical discourse review, becomes an important choice for the alignment of marginalized and oppressed people, including marginalization of local languages, and the exploitation of human resources, cultural resources, and natural resources. For this reason, critical eco-linguistic as a continuation of critical linguistic studies, deserves to be given space as a form of prospective kelinguistic analysis.

Muhlhausler (1996:3) mentions that there are four things that enable the relationship between language and environment, namely: (1) language is free and full of meaning; (2) language created by the world; (3) the world is created by language (the structuralist and post-structuralist view); (4) the language is interconnected with the world (both of which are arranged and arranged but sometimes also free). 
The reciprocal change between environment and language was studied through an eco-linguistic study. Eco-linguistic studies examine ecosystems that are part of the human system (ecology) system with the language people use in communicating in their environment (linguistics). In this case, Sapir (in Fill and Muhlhausler, 2001:14), mentions there are three forms of environment. The first form is a physical environment that covers geographic characters such as topography of a country (coastal, valleys, highlands and mountains, weather conditions, and amount of rainfall). Secondly, the economic environment (human basic needs) consists of fauna, flora, and mineral resources. Third, a social environment that covers the various forces that exist in society that shapes the lives and minds of one another.

Recent eco-linguistic studies are also influenced by one of the other interdisciplinary sciences, namely critical discourse analysis. The combination of these two sciences is called critical eco-linguistic. Critical eco-linguistic examines the discourse about the environment, and various forms of discourse whose ideology concerns people and the environment. The environmental discourse with all its manifestations (oral text, written text, images and internet) is called Greenspeak or Harre's green discourse (in Fill and Muhlhausler, 2001:8). Thus, this critical eco-linguistic investigates the linguistic aspects contained in the discourse or text about the environment.

Fill and Mushausler (2001:11) argue that eco-linguistic is applied linguistics that is crossfield (interdisciplinary). Furthermore, Fill and Muhlhausler (2001:51) explain that eco-linguistic as a broader study of its scope in studying syntax, semantics, and pragmatics, and hence the need for some innovative new theory to investigate these ideas empirically. According to Crystal (2008:161-162), eco-linguistic is a study that reflects the nature of ecology in biological studies, in which the interaction between language and cultural environment is seen as the core: it is also called the language ecology, linguistic ecology and sometimes green linguistics. Alexander and Stibbe (2011) define eco-linguistic as a study of the impact of language use in survival that bridges relationships between humans, other organisms, and the physical environment that is normatively oriented towards the preservation of sustainable relationships and life.

Thus, eco-linguistic is closely related to how language plays a role in, shaping, nurturing, influencing or destroying relationships between people, living conditions and the environment. This is the case with the opinion of Stibbe (2010:1), ecolinguistic evolved as a result of the development of human ecology associated with various systems (economic, social, religious, cultural, linguistic, and ecosystem systems) that are interdependent and related to each other.

Based on the above description, it can be concluded that the study of eco-linguistic has parameters of interrelationships (language and environment interrelations), environment and Haugen's diversity (diversity of language and environment) (in Fill and Muhlhausler, 2001:1). Haugen (1972) (in Mbete, 2009:11-12), states that eco-linguistic has links to ten study spaces, namely: (1) comparative historical linguistics; (2) demographic linguistics; (3) sociolinguistics; (4) dialinguistik; (5) dialectology; (6) philology; (7) prescriptive linguistics; (8) glotopolytics; (9) ethnolinguistics, anthropological linguistics or cultural linguistics (cultural linguistics); and (10) the typology of languages in an environment.

In the scope of an eco-linguistic study, living and used languages illustrate, represent, depict (representing symbolically-verbally) reality in the environment, both physical environment and manmade environment (so cio-cultural environment). It implies language changes as the social and environmental changes change, as Liebert (2001) (in Mbete, 2009:7) states that '... language change ... represents ecological change.' The process of change in the language goes a step in a period of time Long, unknowingly by his speakers, and can not be avoided.

In addition, Sapir (in Fill and Muhlhausler, 2001:2) states that within the scope of ecolinguistic, language and environmental relations exist only on the level of the lexicon, not, for example, at the phonological or morphological level of this interrelation exists merely on the level of the vocabulary and Notes, for example, on that of phonology or morphology. 'This can be presented in the Chart of the Dialogue Model Bang and Døør (Bang \& Door, 1996:47). 
Figure 1.

Model of Three Dimension of Bang \& Door Social Praxis (Lindø \& Bundegaard, 2000)

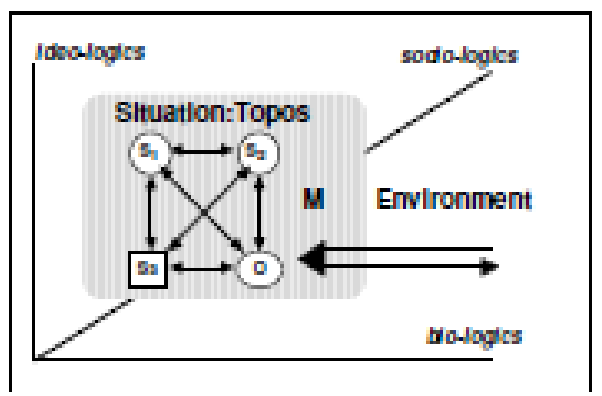

At the level of the lexicon, the dynamics and language changes are influenced by three dimensions (Lindo and Bundegaard, 2000:1011), namely: (a) ideological dimension, ie the ideology of society eg ideology of capitalism supported by market ideology so activity needs to be performed to environmental resources, such as emerging terms and discourses of exploitation, growth, economic gain. Therefore, there are efforts to maintain, develop, and cultivate certain species of fish or plants of high economic value and strong; (b) the sociological dimension, namely the existence of discourse activity, dialogue, and social discourse to realize the ideology. In this dimension language is a meaningful social practical form; And (c) biological dimensions, due to the diversification of lake biota (or marine, or terrestrial) equally within the ecosystem, and with the degree of species vitality and life-span different from each other; There is a large and strong so dominating and 'eat' the weak and small, there is a small and weak so marginalized and inedible. The biological dimension is verbally recorded in lexicon in the word language of each language so that the entities are denoted, and understood. From the theoretical framework, in an eco-linguistic perspective, the language of the environment and the language environment as a metaphorical expression illustrates the comparison of linguistic with the environmental science (ecology) (Mbete, 2003:8).

Furthermore, traditionally, eco-linguistic can be divided into two main parts, namely the analysis of ecocritical and eco-linguistic discourse. The ecocritical discourse is not limited to the application of critical discourse analysis to environmental texts and the parties involved in the environment in the disclosure of the underlying ideologies of the text, but this study also includes analyzing the various discourses that have a major impact on the upcoming ecosystem. For example, the discourse of neo-liberal economics, the inaccessibility of the construction that texts produced by opposing parties differ greatly in the frequency of use of compound words (e.g. relating to lexem cause and responsible). Another linguistic parameter Gerbig uses is emphasis on agents through the use of active, passive and negative sentence constructions.

Critical discourse analysis (CDA) is an attempt or process to give an explanation of a text (social reality) that is willing or being studied by a dominant group or group whose tendency to have a particular purpose to get what it wants. Critical discourse analysis is a relatively new approach of systematic knowledge arising from the tradition of social theory and critical linguistic analysis. This was stated by Fairclough 1995; Titscher, Meyer, Wodak and Vetter, 2000; Wodak and Meyer, 2006; Jorgensen and Philips, 2007). In CDA, the discourse is not solely expressed as a language study. The language analyzed by CDAdoes not describe the aspect of the language alone, but also connects it to the context. The context in this regard means being used for certain purposes including the practice of power.

According to Wodak (2006:1-13), CDA sees the use of both speech and writing language which is a form of social practice. Using discourse as a social practice causes a dialectical relationship between certain descriptive events with the situations, intuations, and social structures that shape them. Discourse practice may present an ideological effect. This discourse can produce and reproduce unequal power relationships between social classes, men and women, majority and minority groups through different representations in the social positions displayed.

Critical discourse analysis aims to help analyze and understand social problems in relation between ideology and power. The aim of CDA is to develop the ideological assumptions contained behind the words in the text or speech in various forms of power. The CDA tries to unite and determine the relationship between (1) actual 
text, (2) discursive practice (this process involves creating, writing, uttering and listening), and (3) the social context associated with text and discursive practice (Fairclough, 2000; Habermas, 2007).

The theoretical framework that can be used to analyze the green text is the Norman Fairclough approach (1992b, 1995a; 199:2000) known as the three-dimensional discourse analysis method. This theory is an advanced framework of critical discourse analysis theoretical framework that has been developed in the publication of the previous Fairclough (1989: 1992a). Essentially, the analysis of three-dimensional discourse is a method of analysis that involves three levels of analysis: (1) textual or textual analysis, which is the description of texts; (2) the practical analysis of discourse or discourse practice (meso level), that interpretation (interpretation) the relationship between the discourse and text; And (3) the sociocultural practice (sociocultural practice), the explanation of the relationship between the discourse process and the social process (Fairclough, 1992a: 73; 1995a: 59).

According to Fairclough (1995a:14), ideology is a proposition that is generally described as an implicit assumption in texts, which contributes to producing power relations, unusual relations of domination. It can be implicit, for example, in the presuppositions of texts. Following the work of French discourse analysis, Fairclough looks at presuppositions as 'preconstruction' elements in a text, elements constructed previously and elsewhere.

Fairclough (1992a:73; 1995b:57; 2000:311) states that the discourse is an important form of social practice that reproduce and transform knowledge, identity and social relationships include relations of power and simultaneously formed by structures and other social practices. Therefore, discourse has a dialectical relationship with other social dimensions. Fairclough shares discourse analysis in three dimensions: (1) discourse text, both oral and written, (2) practical discourse, (3) sociocultural practice. Critical Discourse Analysis the Norman Fairclough model analyzes the text linguistically, by looking at vocabulary, semantics, and sentence. It also incorporates cohesion and coherence, how these interconnections or phrases are combined to form understanding. All the elements analyzed are used to look at the following three problems.

\section{RESEARCH METHODOLOGY}

The research employs critical eco-linguistic design which is the combination of eco-linguistic as the sociological-empirical approach and critical discourse analysis as the critical approach. This research also uses descriptive approach. This is related to the purpose achieved in this study, which is to describe the green discourse news text. The data of this study are texts on green discourse taken from www.unnes.ac.id, Suara Merdeka newspaper, and Kompas news paper. The validity of the data in this study is pursued through the following steps: (1) discussions, (2) re-checking, and (3) consultations, both with conservationists or peers associated with the field of eco-linguistics.

Furthermore, identification methods are used in this sorting activity. Identification means the determination or identification of the data collected in the data corpus. In addition to the method, the data sorting activities also used classification method. The classification in this study means the classification of data based on similarities and differences in data identity. With this method, the already identified data will be classified. Then, the data sorting activity is the research stage which is done after the data collection. In this activity, criteria will be used as the basis of sorting. Methods of data collection conducted in this research are listening method, literature study method, and documentation method (Sudaryanto, 1993:133; Mahsun, 2005:133; Kesuma, 2007: 43).

Then the data has been collected and analyzed in accordance with the formulation of the problem and research objectives. In this study, the green discourse news text in the mass media was analyzed by a critical eco-linguistic study. The collected data are analyzed based on the formulation and the goal of problems. Furthermore, the data were analyzed by the critical eco-linguistic study.

\section{RESULTS AND DISCUSSION}

The analysis of green discourses in critical ecolinguistic is not limited to analyzing microstructures only. The analysis of eco-linguistic green discourse also addresses the issues of language 
macrostructure such as language style, euphemism, and so on. About macrostructure is often used in some text or green discourse. The macrostructures in this green discourse are slightly different from the euphemisms used to replace the taboo. The macrostructures in green discourse are more varied and contain ideological political content. Green discourse is constructed for certain purposes and purposes. Sometimes the discourse is used for campaign or socialization of environmental conservation, as well as criticism of the elements who play a role in environmental damage.

Furthermore, critical eco-linguistic is divided into two parts, namely the part that criticizes the system (grammar) and the part that criticizes the text. Some system or grammatical researchers include M.A.K. Halliday, Andrew Goatly and Mary Schleppergrel. Some textual researchers or eco-critical articles include Harre, Brockmeier and Muhlhausler. The texts studied included political speeches, environmental advertisements, environmental articles, and so forth (Fill and Muhlhausler, 2001:6-7). Critical eco-linguistic analysis itself includes the use of vocabulary, diction, euphemism, dysphemism, and others.

The texts on green discourse uploaded or published in the mass media are presented in the following data.

\section{Data 1 (News Text I)}

SBY: UNNES is excellent. This is Conservation University

(Wednesday, $30^{\text {th }}$ of March 2016, source: webpage www.unnes.ac.id.)

This is the comment of President of the 6th RI Prof. Dr. Susilo Bambang Yudhoyono when entering the State University of Semarang (Unnes) Auditorium of Sekaran campus, on Wednesday (30/3). Very good. This is new conservation! 'He said who was immediately greeted by the handshake Unnes Rector Prof. Dr. Fathur Rokhman MHum. (P1)

\section{Data (News Text II) \\ Collaborating with Pertamina, UNNES Planted 200 Trees at Kandri}

(Monday, $8^{\text {th }}$ of December 2014, source: Suara Merdeka)

SEMARANG - Recently, Semarang State University (Unnes) in collaboration with Pertamina and Semarang City Government planted trees in Kelurahan Kandri, Gunungpati, Semarang. (P1)

This activity is a collaboration between Semarang State University through Institute of Research and Community Service (LP2M) with Pertamina and Semarang City Government in Partnership Program of Community Development (PKBL). As quoted from the official website of Unnes, the planting activities of 200 trees, which includes guava, durian, and kelengkeng, this involves many parties. Namely General Manager Marketing Operations Region IV Pertamina, Area Manager SME and SR partnership, the leader of the bank bni, rector, head of agency, head of department, subdistrict and local lurah. (P2)

The purpose of this program is the establishment of eduwisata village and the economic area of the community and is expected to become an agro-tourism area and can also be used by school students to learn. (P3)

Head of Agricultural Service WP. Rusdiana said this potential should be explored, and this is an opportunity for Semarang City to advance the tourist village, which will become a new tourist village with local potentials. (P4)

He said the Mijen and Gunungpati areas are areas of agricultural development, both livestock and food, horticulture, herbs, and ornamental plants. According to the plan, the official gardens in Kandri are one place where plans will be named smart farmers' homes that can be used for gathering places and can contribute to Semarang City Government. (P5) 
Rector of State University of Semarang, Prof. Dr. Fathur Rokhman MHum said that regional potencies such as mango, jambu, rambutan, durian need to be conserved. The effect can be as a buffer of water and also the habitat of animals. For that future effort is maintenance and Unnes will help marketing. (P6)

\section{Data 3 (News Text III)}

Campus Environment, Healthy with Cycling (Tuesday, $4^{\text {th }}$ of March 2014, source: K OMPAS )

Entering the campus environment of Semarang State University in Sekaran, Gunungpati, Semarang, Central Java, coolness ambushed. Rimbun trees welcome. The security guard guards in front of the gate and directs the motorcycle or car to park before entering the campus. (P1)

Rector Unnes Fathurrahman revealed, the policy of walking and cycling on campus is one part of Unnes's commitment as a conservation university. "This is our contribution as an educational institution to help overcome the problem of global warming. Conservation efforts have been included in Unnes's statute since 2010, 'he said. (P9)

Each student is required to plant at least one tree. The tree is a requirement for students who will do thesis. (P10).

The three news texts above are texts on green discourse. This is because the three examples of news texts show that the mass media in this case, namely the page www.unnes.ac.id, Suara Merdeka, and Kompas using linguistic units in the form of text news about the green discourse as a means of building reader opinion. For that, in the news in the mass media found the green discourse. This indicates a link between language and environment.

Then, in the first news text, the subject of conservation-oriented universities is getting stronger. This is demonstrated by the recognition of the 6th President of the Republic of Indonesia,
Mr. Susilo Bambang Yudhoyono, who stated 'Unbelievable! Very good. This is new conservation! '. In fact, there is a message from this news text, so that other universities can follow what has been done by UNNES. This shows that conservationbased universities provide a positive image and reproduce UNNES. It seems that conservationminded universities will become a trendsetter that will be followed by other universities. This shows the existence of a linguistic expression of euphemism.

In the second news text, there is a message to be conveyed that efforts to create an atmosphere of conservation is needed cooperation with other instusi, namely pertamina. This report shows that to imaged and repute conservation-based universities need to involve parties outside the campus. In addition, there is an interesting linggual unit of this news, namely Pertamina tandem, Unnes Plant 200 Trees in Kandri Village. The use of the word choice is usually done to humans or people, for example: 'Mother took my sister', 'Daddy took my grandmother'. But in the text, the word coupled with the word pertamina. This shows that in the text of conservation news in mass media can be found the existence of linguistic expression in the form of metaphor.

Furthermore, in the news text three, there is a message to be conveyed that one of the pillars in the conservation of Natural Resources and the environment also received special attention. The policy of transporting by bicycle in the campus area becomes a movement conducted at conservation-minded universities. On the other hand, this condition is juxtaposed with several other universities. Each cycling policy in a college campus environment has its advantages and problems. In addition, lingual units of coolness phrases ambushed, lush trees welcome, as well as sterile from motor vehicles indicate the choice of words that utilize the expression of language in the form of personification. This personification becomes a beauty in packing news about Campus Healthy Environment with Cycling, which is a sympathetic invitation to all campus residents.

Based on the analysis of data, there are five functions of lexicons found in the green discourse: (a) naming; (b) describing a situation; (c) describing activity; (d) describing places, and 
$€$ describing character. The five functions are categorized into (a) biotic of flora and fauna and (b) abiotic. Trampe in Fill and Muhlhausler (2001:238239) states that environmental discourse or green discourse in mass media usually contains the following: (1) reification, which treats living things as objects of economic value, related to technology and ideology. For example, living things or resources can be produced, optimized, managed, and used (utilized); (2) hiding the fact, ie the use of euphemism to replace some words or terms that are avoided. For example relating to death, destruction or destruction, extermination or annihilation, and poison; (3) to declare hatred or resistance against those who damage traditional land or customs; and, (4) creating slogans and elements that convey ideas and ideas used to make the process of environmental and cultural destruction undertaken by a group of people seems as appropriate and in line with the laws of nature.

Schultz (in Fill and Muhlhauster, 2001:109110) stated that there are three linguistic or linguistic tools that are often used in texts related to the commercialization of the environment. First, the use of neutral words that have the connotation of praise or tend to side with exploitation, but the reality represented by the word is very different. The example is the use of words or terms which refer to ecologically sustainable development, fertilizer and human resources. Secondly, the tools that are often used, namely the use of euphemism (the mention of objects or something unpleasant to be politer). The example is the use of the term clearing, harvest, greenhouse effect and global warming. The third examples are the rarely used tools but very powerful effects when used, ie the use of peyorative terms or dysphism (mention of a sign or something with a more negative connotation). For example, the use of word or term earthworm food and animal's homes to mention humus.

The above green discourse texts are constructed to fulfill some goals. The construction of the texts can bee seen from the arrangement of the news texts. There are some used to socialize and sustain environmental conservation, to criticize the parties who contribute to environmental damages. This is because the environmental news texts are able to influence logics, feeling, and environmental attitude of people involved in the news such as writer and readers. Therefore, the critical discourse analysis by Fairclough does not only see the texts as a dead thing but also it sees as a text correlated to the social system which becomes the background and the goals of the text it self.

Language researchers may indeed choose one of a number of linguistic aspects to study, in microlinguistic or macrolinguistic umbrellas, theoretical linguistics or pure linguistics or applied linguistics. Both are just as important. Pure linguistics (microlinguistik) is very important to be developed through in-depth research for the development of linguistic theory, including Indonesian linguistics and Indonesian languages as it will in turn sustain the development and development of applied linguistics.

According to Mbete $(2003: 14)$, many linguistic, micro and macro, pure and applied issues, monodisciplinary and interdisciplinary, especially under the umbrella of eco-linguistic, are interesting to be identified and developed in research. Many linguistic phenomena in green discourse that can be studied specifically and deeply for thesis writing, thesis, or dissertation..

Specifically, applied linguistics, with critical eco-linguistic, is directly linked to learning and language education, both in Indonesian, regional languages, and foreign languages in Indonesia. In that regard, the learning and education of those languages, it is necessary to develop an environmentally oriented learning framework by presenting a variety of green discourse texts. The results of research on local wealth and natural resources recorded verbally and nonverbal, are very important and strategic learning material. Important and strategic with the development of environmentally sound learning materials, learners begin to recognize, understand, appreciate, and love their environmental resources. At the end of the new generation will nourish, care, and preserve their environment. The efforts of language-based language education with the use of green discourse will be very helpful and overcome the symptoms of youth's ignorance with their environment, both natural and socio-cultural.

This study found representations of ideological, sociological, and biological meanings. This can be presented in the following analysis. 


\section{Representation of Ideological Meaning}

Lindo and Bundsgaard (2000: 11) suggest that ideological functions and meanings are related to the individual's cognitive, ideological, and psychological mentality. Here is a quote of data that represents the meaning of the ideology.

\section{Data 4}

On the agenda of Indonesia's Independence Day ceremony this year, the Rector of Universitas Negeri Semarang distributed local seeds and scholarships to a number of underprivileged students. The distribution of seeds to new students is in line with UNNES' commitment as a conservationbased university. (121/ WB / 17 August 2016).

\section{Data 5}

Conservation, according to Rector, is essentially a high-end principle of protection, preservation, utilization, and sustainable development of the natural resources and noble culture of the nation. "From the choice of theme, the title of this work has indeed been dedicated as an activity that is in line with the conservation vision," said Rector. (47 / WB / 26 June 2012).

Ideological representations are constructed by a group or agency to reproduce and legitimize their dominance with their primary strategy of awareness-raising that the dominance is accepted or taken for granted. Ideology has several important implications. First, ideology is inherently social and not personal. Ideology requires sharing among group members or organizations to form a solidarity and unity of steps in acting and behaving. Second, although it is social, ideology is used internally among group members or communities. Ideology is general, abstract, and shared values among group members to provide a basis for how a problem should be seen. With this view, discourse is understood to be neutral and takes place naturally but contains ideology to dominate and seize influence.

This is in line with the data quote from the above green discourse. In the text, the representation of the meaning of ideology is based on the specific meaning or a special ideology of UNNES as a conservation university. The representation of the ideological meaning of the conservation university and conservation campuses in the above data refers to UNNES as the University of Conservation, a university which in the implementation of the tridharma of higher education refers to conservation principles or insights which include: protection, preservation, sustainable use, conservation of Natural Resources, as well as cultural arts.

\section{Representation of Sociological Meaning}

Sociological relationships are related to the way humans organize their relationships with one another. Therefore, the sociological representation of meaning also refers to how the lingual unit can be used as a means of interaction and mobilizing other people or a particular group. Based on the analysis in the conservation news text, here is a fragment of data that represents the sociological meaning.

\section{Data 6}

Universitas Negeri Semarang is committed to realize a humanist campus. One of its efforts is by implementing policies on green transportation. On days and working hours, motor vehicles are not allowed to enter this conservation campus area. (69/ WB / 6 January 2013)

\section{Data 7}

The distribution of seeds to new students is in line with UNNES commitment as a conservation-based university. Each plant that is symbolically distributed in the ceremony represents eight conservation values: inspirational, humanist, caring, innovative, creative, sportive, honesty and fairness. (121 / WB / 17 August 2016)

The sociological significance is based on the notion that every cultural fact is born and thrives under certain sociohistorical conditions. 
Ideological meanings represent interactions or relationships between individuals or groups of people in a society. The sociological significance in lingual units centers on how an ecollexic may represent attitudes that reflect the nature of values and character. The data above found a representation of sociological meaning in the word 'inspirational, humanist, caring, innovative, creative, sportsmanship, honesty, and justice'. These eight values are represented in green discourse in the hope that social interactions are always based on human values.

\section{Representation of Biological Meaning}

The representation of biological meanings governs human relationships with other species in their environment. Harmonization between humans and other species is evidence of adaptation in an environment. Harmonization can be maintained if the link between humans and the environment can still adapt, interact, interrelate, even interdependent with each other. Here are the data that represents a biological meaning.

\section{Data 8}

Faculty of Engineering (FT) Universitas Negeri Semarang (UNNES) commemorate the earth day by doing reforestation in the area around Jatibarang Reservoir, Wednesday (22/4). The activity is one concrete form of conservation of green belt led Jatibarang Reservoir. (103 / WB / 22 April 2013).

\section{Data 9}

The action did not only stop there. In the activity with theme Every Day is Earth Day, Mahapala UNNES also socialized love of elementary school environment in Gunungpati in the form of counseling and training about conservative lifestyle, organic waste management practice in the form of compost. (75 / WB / 22 April 2013.)

The biological dimension relates to the human biological collectivity coexisting with other species (animals, plants, soil, sea, etc.) (Lindo and
Bundsgaard, 2000: 11). The above quoted data indicates some lingual units that have biological significance because of their relation to the biological side of humans adjacent to other species within an ecosystem.

The representation of the biological meaning of a green belt (green belt) is a green open space that aims to limit the development of land use or limit the activity of one with other activities so as not to interfere with each other. The meaning represents an effort to maintain the balance of ecosystems by maintaining the infiltration area and open areas that planted trees as the lungs of the city. The lingual unit of organic waste represents the human effort to sort waste by its type and usefulness for the ecosystem. Organic garbage is the waste that comes from plants and is easy to recycle. Various representations of biological meaning prove that the green discourse has a close relationship with the biological aspects.

\section{CONCLUSION}

Based on the critical eco-linguistic study, in the green discourse in the mass media, this study found lingual units that represent the ideological, sociological, and biological meaning. This interdisciplinary linguistic umbrella, if developed more empirically, factually, and conceptually, can be a source of inspiration in identifying the various environmental issues around us, in the effort to dissect mutual relationships between people, humans and nature, as well as about diversity itself. Thus, critical eco-linguistic as meaningrich and value-free study can offer material for solving various human, community, and cultural problems. For this reason, critical eco-linguistic as the sustainability of eco-linguistic studies and critical linguistic studies is worthy of space in the context of environmental issues. The balance between formal linguistic studies and critical linguistics, including critical discourse review, becomes an important option for alignment with the exploitation of human resources, cultural resources, and natural resources. To that end, the results of this study can contribute theoretically and practically to the fields of linguistics, language learning, journalism, and public policy. 


\section{ACKNOWLEDGEMENT}

The author gives thanks to Prof. Dr. I Dewa Putu Wijana, S.U., M.A. from Universitas Gadjah Mada and Prof. Dr. Aron Meko Mbete from Universitas Udayana who has given scientific horizons related to discourse and eco-linguistic studies.

\section{REFERENCES}

Alexander, R. \& Stibbe, A. (2011). From the Analysis of Ecological Discourse the Ecological Analysis of Discourse in Language Sciences. Amstredam: Elsevier.

Bang, J. C., \& Døør, J. (1996). Language and TruthDialogue and Dialectics. In Sprachökologie Und Ökolinguistik (pp. 17-26). Stauffenburg Verlag Brigitte Narr GmbH.

Crystal, D. (2011). Dictionary of linguistics and phonetics (Vol. 30). John Wiley \& Sons.

Eriyanto (2012). Analisis Wacana: Pengantar Analisis Teks Media [Discourse Analysis: Introudction to Analysis of Text and Media. Yogyakarta: Lembaga Kajian Islam dan Sosial (LKIS).

Fairclough, N. (1989). Language and Power. Harlow: Longman.

Fairclough, N. (1992a). Discourse and Social Change. Cambridge: Polity Press.

Fairclough, N. (1992b). Discourse and Text: Linguistic and Intertextual Analysis. Cambridge: Polity Press.

Fairclough, N. (1995). (1995a) Media Discourse. London: Edward Arnold.

Fairclough, N. (1995b). Critical Discourse Analysis: The Critical Study of Language. HarlowEssex: Longman Group Limited.

Fairclough, N. (2000). Critical analysis of media discourse. Media studies: A reader, 2.

Fill, A., \& Mühlhäusler, P. (2001). The eco-linguistics reader. Language, ecology and environment.

Habermas, J. (2007). Teori Tindakan Komunikatif II: Kritik atas Rasio Fungsionalis. Yogyakarta: Kreasi Wacana.

Haugen, E. (1972). The Ecology of Language. in Alwin Fill and Peter Mühlhäusler (ed) The Eco-linguistic Reader Language, Ecology, and Environment. London: Continuum.

Jorgensen, M. W., \& Phillips, L. J. (2007). Analisis Wacana Teori dan Metode. Yogyakarta: Pustaka Pelajar.
Kesuma, T. M. J. (2007). Pengantar (Metode) Penelitian Bahasa. Yogyakarta: Caravatibooks.

Lindø, A. V. \& Bundsgaard, J. (eds) (2000). Dialectical Eco-linguistics Three Essays for the Symposium 30 Years of Language and Ecology in Graz December 2000. Austria: Univerisity of Odense Research Group for Ecology, Language, and Ecology.

Mahsun (2005). Metode Penelitian Bahasa: Tahapan Strategi, Metode, dan Tekniknya. Ed. Revisi. Jakarta: Raja Grafindo Persada.

Mbete, A. M. (2003). Bahasa dan Budaya Lokal Minoritas: Asal-Muasal, Ancaman Kepunahan, dan Ancangan Pemberdayaan dalam Kerangka Pola Ilmiah Pokok Kebudayaan. Universitas Udayana Bidang Sastra \& Budaya, 83.

Mbete, A. M. (2009). Selayang Pandang Tentang Ekolinguistik: Perspektif Kelinguistikan Yang Prospektif. Bahan Untuk Berbagi Pengalaman Kelinguistikan dalam Matrikulasi Program Magister Linguistik Program Pascasarjana Universitas Udayana, 12.

Stibbe, A. (2010). Eco-linguistic and Globalisation. in Nikolas Coupland (ed) The Blackwell Handbook of Language and Globalisation. London: Blackwell.

Sudaryanto (1993). Metode dan Aneka Teknik Analisis Bahasa: Pengantar Penelitian Wahana Kebudayaan secara Linguistis. Yogyakarta: Duta Wacana University Press.

Sudibyo, A. (2006). Politik Media dan Pertarungan Wacana [Polictical Media and Discourse Struggle]. Yogyakarta: LkiS.

Titscher, S., Meyer M., Wodak, R., \& Vetter, E. (2000). Methods of Text and Discourse Analysis. London: Sage Publications.

Wodak, R. (2006). Mediation between discourse and society: assessing cognitive approaches in CDA. Discourse Studies, 8(1), 179-190.

Wodak, R., \& Meyer, M. (Eds.). (2009). Methods for critical discourse analysis. London: Sage Publications 